\title{
Persepsi dan preferensi masyarakat terhadap ruang publik tepi sungai (studi kasus: Tukad Bindu)
}

\author{
Raraskova Dennira1, I G. A. A. Rai Asmiwyati' ${ }^{1 *}$, Ni Luh Made Pradnyawathi² \\ 1. Prodi Arsitektur Pertamanan, Fakultas Pertanian Universitas Udayana, Jl. P.B. Sudirman, Denpasar, \\ Indonesia \\ 2. Prodi Agroekoteknologi, Fakultas Pertanian Universitas Udayana, JI. P.B. Sudirman, Denpasar, Indonesia
}

\section{*E-mail : asmiwyati@unud.ac.id}

\begin{abstract}
Perceptions and preferences toward Tukad Bindu riverside area as public space. Government of Denpasar City has transformed several river banks into public spaces. One of them is Tukad Bindu that was designed with the dominance of vegetation that makes a natural impression. The purpose of this research was to discover the perceptions and preferences toward Tukad Bindu riverside area as a public space. This study used survey method and data processing with tabulations. This study used questionnaires as tools and materials. The result of this study showed that the user's distance is dominated by $1-5$ kilometer and there was no negative responses whose the percentage exceeded the positive responses. Positive responses were strongly agree $(S A)$ and agree $(A)$, negative responses are disagree $(D)$ and strongly disagree $(S D)$, and neutral $(\mathrm{N})$ is considered to no comment at all. Based on general observation users were more interested in public spaces dominated by softscapes.
\end{abstract}

Keywords : Denpasar, Perceptions, Preferences, Tukad Bindu River.

\section{Pendahuluan}

Saat ini, Pemerintah Kota Denpasar menata beberapa sungai di Denpasar menjadi sebuah ruang publik. Salah satunya adalah Tukad Bindu yang telah dikembangkan sebagai objek rekreasi di Kota Denpasar sebagai bagian dari program kali bersih Kota Denpasar sejak Tahun 2010. Sebelum ditata, Tukad Bindu sering difungsikan sebagai tempat pembuangan limbah rumah tangga. Kondisi di Tukad Bindu saat ini didominasi oleh softscape sehingga mampu memberikan kesan alami. Evaluasi mengenai desain Tukad Bindu oleh masyarakat masih jarang dilakukan sejak selesainya penataan ulang Tukad Bindu.

Penelitian mengenai desain ruang publik tepi sungai serta aktivitas masyarakat yang ada di sekitarnya telah banyak dilakukan di Indonesia, tetapi penelitian yang membahas mengenai persepsi dan preferensi masyarakat akan keberadaan ruang publik kawasan tepi sungai yang telah ditata masih sedikit. Padahal mengetahui preferensi publik terhadap ruang publik kawasan tepi sungai merupakan salah satu bagian penting dalam proses perancangan. Sama seperti memikirkan manfaat yang akan didapatkan dalam desain tersebut, reaksi masyarakat juga akan membantu dalam menentukan desain yang terbaik (Jungels et al., 2013). Hasil studi sebelumnya mengenai kawasan tepi sungai di Illinois, Amerika Serikat, menunjukkan bahwa masyarakat lebih menyukai desain sempadan sungai yang didominasi oleh vegetasi dibandingkan dengan perkerasan (Kenwick et al., 2009).

Penelitian ini bertujuan untuk mengetahui persepsi dan preferensi masyarakat terhadap keberadaan ruang publik kawasan tepi Tukad Bindu yang telah ditata. Mengetahui persepsi dan preferensi publik terhadap ruang publik kawasan tepi sungai penting dalam proses perancangan. Hasil dari studi ini diharapkan dapat menjadi masukkan dan data untuk desain dan rekomendasi ruang publik kawasan tepi sungai selanjutnya.

\section{Metode}

Penelitian berlangsung selama tiga bulan yaitu mulai November 2018 sampai dengan Juli 2019 di kawasan ruang publik tepi sungai di kota Denpasar yaitu Tukad Bindu. Penelitian ini menggunakan metode survei. Alat yang digunakan pada penelitian ini adalah alat tulis dan aplikasi Microsoft Excel. Bahan yang dibutuhkan dalam penelitian adalah lembar kuesioner dan foto. 


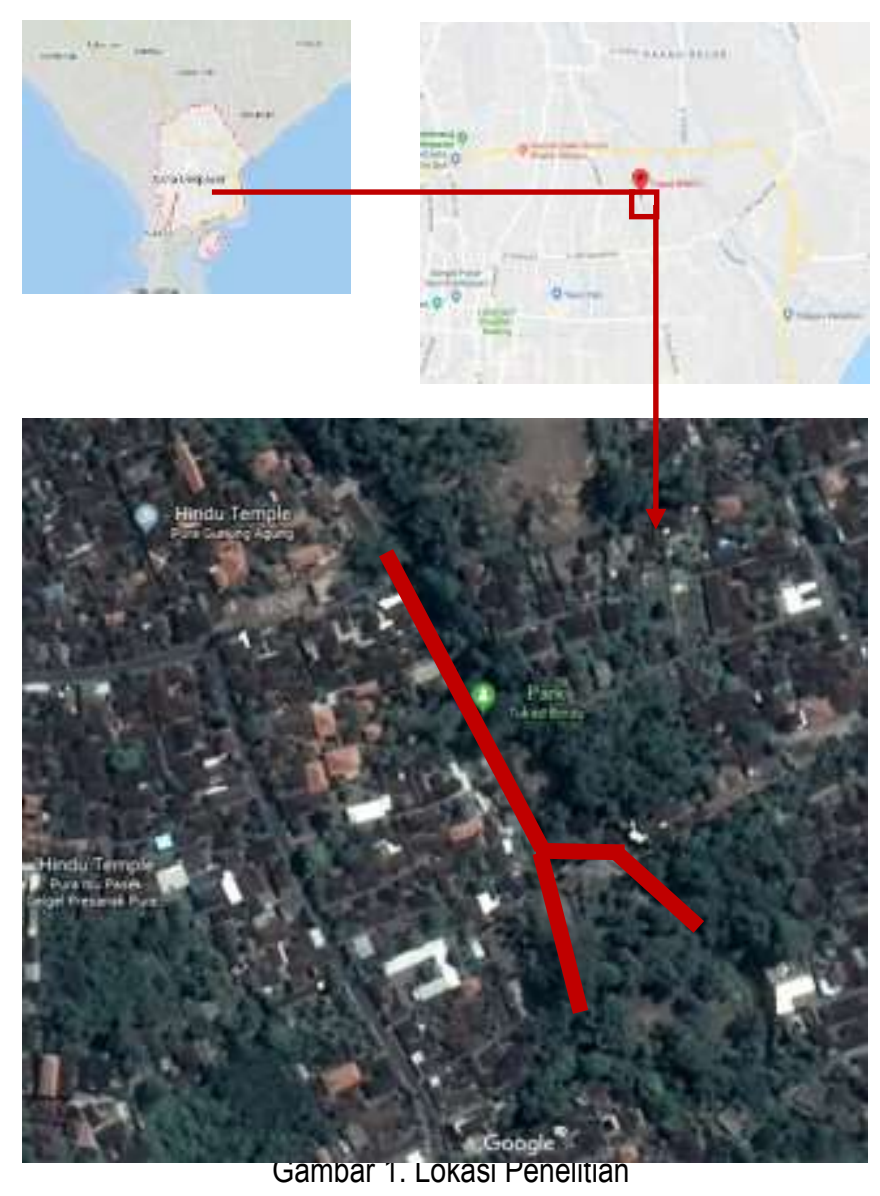

(Sumber gambar: www.google.com)

\subsection{Metode Pengumpulan Data}

Penelitian menggunakan metode survei dengan tiga tahap. Tahap pertama yaitu persiapan dan inventarisasi data, tahap kedua yaitu analisis dengan tabulasi data, dan tahap ketiga yaitu analisis dan sintesis deskriptif.

\subsubsection{Inventarisasi}

Tahap inventarisasi dilakukan studi literatur dan survei berupa kuesioner terkait dengan reaksi masyarakat terhadap ruang publik tepi sungai. Penentuan jumlah sampel yang representatif menurut Hair (1995) adalah tergantung pada jumlah indikator dikali 5 sampai dengan 10. Jumlah sampel pada penelitian ini adalah:

$$
\begin{aligned}
\text { Sampel } & =\text { jumlah indikator } \times 5 \\
& =9 \times 5 \\
& =45
\end{aligned}
$$

Berdasarkan perhitungan di atas jumlah sampel yang akan digunakan adalah sebesar 45 responden di setiap lokasi penelitian. Jumlah minimal responden pada penelitian adalah 30 berdasarkan acuan umum untuk menentukan ukuran sampel. Ukuran sampel lebih dari 30 dan kurang dari 500 responden adalah tepat untuk penelitian. Jika sampel dipecahkan ke dalam sub sampel, ukuran sampel minimum adalah 30 untuk tiap kategori (Sekaran, 2006).

Penelitian ini menggunakan teknik purposive sampling yang artinya menentukan ukuran sampel dengan pertimbangan tertentu (Sugiyono, 2011). Pada penelitian ini sampel yang digunakan memiliki ketentuan dengan batas usia minimal 18 tahun dengan anggapan telah memiliki pengetahuan yang dibutuhkan 
untuk mengisi kuesioner penelitian. Responden dipilih langsung di lokasi penelitian. Penyebaran kuesioner dilakukan pada lokasi penelitian yaitu Tukad Bindu dengan waktu pengambilan data setiap hari pada siang sampai dengan sore hari. Waktu penyebaran kuesioner dipilih pada siang sampai dengan sore hari karena dapat menunjukkan aspek kenyamanan yang diberikan oleh objek penelitian. Sebelum dilakukannya penyebaran kuesioner lebih lanjut, dilakukan pre-test kuesioner. Pre-test dilakukan untuk menyempurnakan kuesioner. Pre-test dilaksanakan di luar daerah penelitian dengan jumlah 30 responden. Responden pada pretest adalah mahasiswa arsitektur lanskap yang sudah pernah mengunjungi Tukad Bindu. Hasil dari pre-test ini diketahui adanya pertanyaan yang kurang relevan, penggunaan bahasa yang sulit dimengerti, dan kecepatan responden mengisi kuesioner. Perbaikan kuesioner dari hasil pre-test dilakukan sebelum kuesioner penelitian disebarkan.

Jenis kuesioner yang digunakan dalam penelitian ini adalah kuesioner tertutup. Jawaban dari pertanyaan berupa skala likert dan pilihan berganda. Pertanyaan dikelompokkan menjadi empat kategori, yaitu familiarity, nilai fungsi yang dimiliki, keindahan (aesthetic), dan karakteristik responden. Tujuan dari kategori pertanyaan karakteristik adalah untuk mengetahui identitas responden, yaitu jenis kelamin, usia, pendidikan terakhir, pekerjaan, intensitas, dan jarak. Tujuan dari karakteristik familiarity adalah untuk mengetahui seberapa besar minat responden terhadap lokasi tersebut. Pertanyaan untuk nilai fungsi menunjukkan kepada persepsi responden terhadap fungsi dari ruang publik sempadan sungai. Nilai estetika menunjukkan pada persepsi dan preferensi responden terhadap keindahan sempadan sungai. Isi dari kuesioner untuk persepsi didapatkan dari studi pustaka yang bersumber dari tujuan, fungsi, dan manfaat dari bantaran sungai dan ruang terbuka publik. Kuesioner mulai disebar pada tanggal 12 November 2018, pada siang sampai dengan sore hari dan berakhir pada tanggal 23 Desember 2018.

\subsubsection{Tabulasi Data}

Sesuai dengan tujuan dari penelitian, metode pengolahan data yang digunakan dalam penelitian ini adalah metode tabulasi data dalam bentuk frekuensi (\%). Teknik tabulasi data dalam bentuk frekuensi digunakan untuk menghitung jumlah pilihan responden dibandingkan dengan jumlah keseluruhan pilihan dalam bentuk persentase. Perhitungan Persentase dilakukan dengan menggunakan rumus (2), yaitu :

$$
P=\frac{f}{n} \times 100 \%
$$

Keterangan :

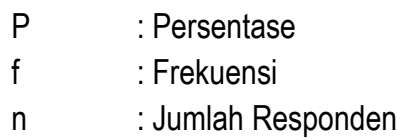

\subsubsection{Analisis dan Sintesis Data}

Data yang dianalisis dengan menggunakan teknik tabulasi ini adalah data karakteristik responden, persepsi responden terhadap Tukad Bindu, serta preferensi masyarakat mengenai desain tepi sungai. Analisis ini dilakukan untuk mengetahui karakteristik responden, persepsi pengguna terhadap nilai estetika dan nilai fungsi Tukad Bindu, serta preferensi masyarakat mengenai desain tepi sungai untuk rekomendasi penataan ruang publik tepi sungai selanjutnya. Nilai dari hasil data kuesioner dibagi menjadi dua kategori, yaitu kategori nilai positif adalah persepsi sangat setuju (SS) dan setuju (S), kategori nilai negatif adalah persepsi tidak setuju (TS) dan sangat tidak setuju (STS), sedangkan persepsi netral (N) dianggap tidak memberikan nilai. Tahap analisis dan sintesis dalam penelitian ini membahas mengenai karakteristik pengguna Tukad Bindu, persepsi pengguna mengenai Tukad Bindu, serta rekomendasi dari hasil preferensi masyarakat terhadap desain tepi sungai.

\section{Hasil dan Pembahasan}

\subsection{Gambaran Umum Tukad Bindu}

Tukad Bindu berada di Gang Sakarini, Kesiman, Denpasar Timur, Kota Denpasar. Penataan Tukad Bindu sebagai tempat rekreasi dimulai tahun 2010 sebagai bagian dari program kali bersih kota Denpasar. Sebelum ditata, Tukad Bindu sering difungsikan sebagai tempat pembuangan limbah rumah tangga. Sebagai 
bentuk dukungan terhadap program kali bersih di Denpasar, Kelihan Banjar Ujung dan masyarakat yang tergabung dalam banjar ikut terlibat aktif dalam kegiatan penataan Tukad Bindu.
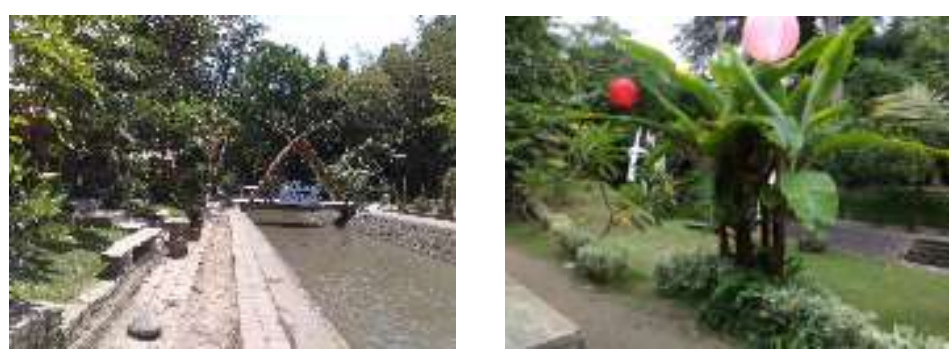

Gambar 2. Tukad Bindu

Hasil dari observasi fasilitas fisik yang dapat dijumpai pada rekreasi Tukad Bindu pada saat ini yaitu, lahan parkir kendaraan, jembatan, toilet umum, tempat penyewaan ban dan selancar air, tempat bermain anak, dan lapangan olahraga. Tanaman yang berada di Tukad Bindu adalah tujuh jenis tanaman strata pohon, 12 jenis tanaman strata perdu dan semak, dua jenis penutup tanah, satu jenis bambu, dan satu jenis paku (Tabel 1). Binatang yang dapat ditemui di lokasi Tukad Bindu adalah burung dan ikan.

Tabel 1. Daftar Tanaman di Tukad Bindu

\begin{tabular}{|c|c|c|}
\hline No. & Nama Tanaman & Nama Latin \\
\hline A. & Pohon & \\
\hline 1. & Kamboja & Plumeria sp. \\
\hline 2. & Pepaya & Carica papaya L. \\
\hline 3. & Pisang & Musa sp. \\
\hline 4. & Mangga & Mangifera indica \\
\hline 5. & Daun kupu-kupu & Bauhinia purpurea \\
\hline 6. & Sawit & Elaeis guineensis \\
\hline 7. & Belimbing & Averrhoa carambola \\
\hline B. & Perdu dan Semak & \\
\hline 1. & Andong & Cordyline terminalis \\
\hline 2. & Puring & Codiaeum variegatum \\
\hline 3. & Perasok & Cordyline australis \\
\hline 4. & Soka & Ixora javanica \\
\hline 5. & Sambang Merah & Excoecaria cochinchinensis \\
\hline 6. & Pisang hias & Heliconia sp. \\
\hline 7. & Bunga matahari & Helianthus annuus $L$. \\
\hline 8. & Li kuan yu & Vernonia elliptica \\
\hline 9. & Jempiring & Gardenia jasminoides \\
\hline 10. & Iris kuning & Iris pseudacorus \\
\hline 11. & Kembang sepatu & Hibiscus rosa-sinensis L. \\
\hline 12. & Walisongo & Schefflera arboricola \\
\hline C. & Penutup Tanah & \\
\hline 1. & Aracis & Arachis hypogaea \\
\hline 2. & Wedelia & Sphagneticola trilobata \\
\hline D. & Bambu & \\
\hline 1 & Bambu kuning & Bambusa vulgaris \\
\hline E. & Paku & \\
\hline 1. & Paku tanduk rusa & Platycerium bifurcatum \\
\hline
\end{tabular}




\subsection{Karakteristik Responden Tukad Bindu}

Karakteristik merupakan alat ukur statistik yang penting untuk suatu penelitian. Dari hasil penyebaran kuesioner diperoleh karakteristik pengguna Tukad Bindu seperti pada Gambar 3. Karakteristik seseorang dapat mempengaruhi persepsi terhadap suatu objek.

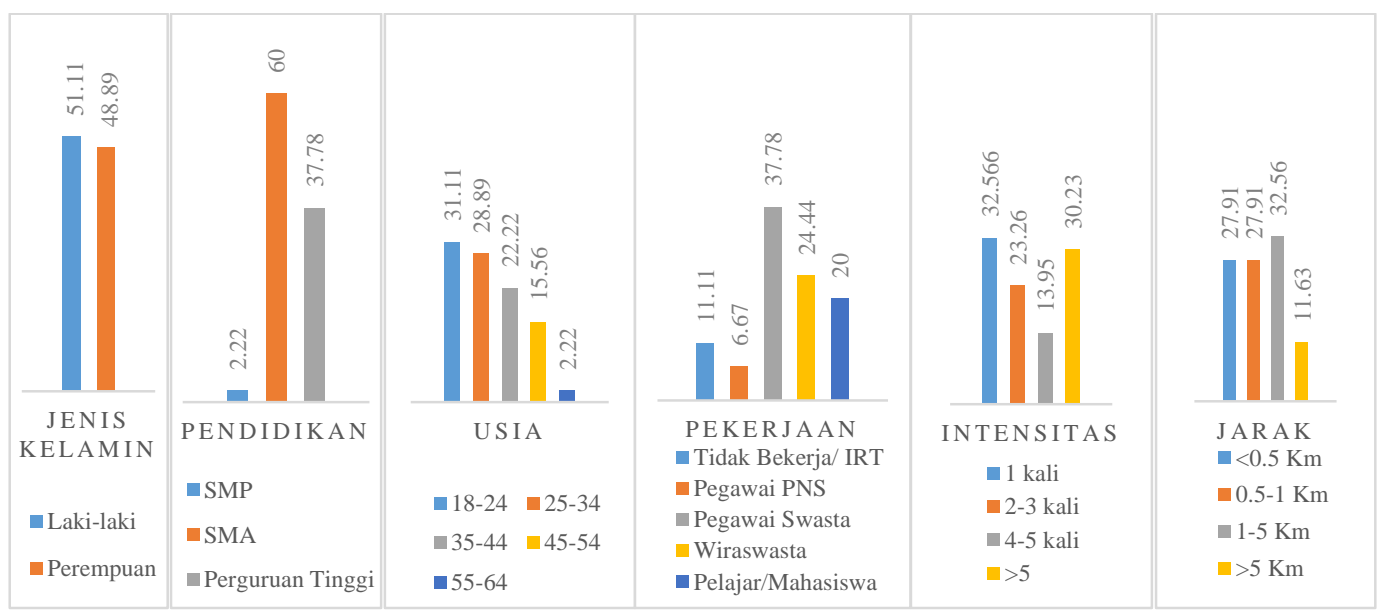

Gambar 3. Karakteristik Responden Pengguna Tukad Bindu

Hasil dari inventaris data Tukad Bindu didominasi oleh pengunjung dengan jenis kelamin laki-laki. Pengunjung didominasi oleh usia 18-24 tahun yang menunjukkan tempat ini menarik bagi pengunjung dengan kelas usia muda yang produktif. Tukad Bindu didominasi oleh pengunjung yang berpendidikan terakhir SMA. Dari segi profesi, Tukad Bindu banyak dikunjungi oleh pegawai swasta.berdasarkan observasi, pengunjung Tukad Bindu didominasi oleh orangtua yang berkunjung dengan mengajak serta anaknya untuk bermain. Dari segi intensitas, Tukad Bindu didominasi oleh pengunjung yang baru pertama kali berkunjung. Tukad Bindu didominasi oleh pengunjung dengan jarak tempuh $1-5 \mathrm{~km}$, hal ini dapat menunjukkan bahwa masyarakat cenderung mengunjungi tempat rekreasi yang jaraknya relatif dekat dan mudah dijangkau dari tempat tinggal mereka. Jarak ini dapat menjadi salah satu acuan untuk menempatkan ruang terbuka publik.

\subsection{Persepsi Responden terhadap Tukad Bindu}

Berdasarkan Gambar 4 dan Gambar 5 dapat diketahui bahwa sebagian besar responden memiliki persepsi yang positif terhadap nilai fungsi Tukad Bindu. Secara rinci pendapat bahwa Tukad Bindu kaya dengan tumbuh-tumbuhan dan binatang responden memilih setuju $60 \%$ diikuti sangat setuju $20 \%$, netral 15,56\%, dan tidak setuju 4,44\%. Pendapat bahwa desain sempadan Tukad Bindu dapat mengurangi polusi, responden memilih setuju $48,89 \%$ diikuti sangat setuju $42,22 \%$, netral $4,44 \%$, dan tidak setuju $4,44 \%$. Responden setuju dengan fungsi sempadan Tukad Bindu dapat menjadi penahan erosi adalah $62,22 \%$ dikuti sangat setuju $20 \%$, netral $11,11 \%$, dan tidak setuju 6,67\%. Nilai fungsi sempadan Tukad Bindu dapat menjadi tempat berlindung bagi binatang akuatik dan binatang liar menurut responden adalah sangat setuju $13,33 \%$, setuju 48,89\%, netral 22,22\%, dan tidak setuju 15,56\%. Pendapat bahwa Tukad Bindu dapat menjadi ruang komunikasi bagi masyarakat responden menjawab sangat setuju $42,22 \%$, setuju $51,11 \%$, dan netral $6,67 \%$. Terhadap nilai fungsi bahwa Tukad Bindu dapat menstimulasi kreativitas dan produktivitas masyarakat responden menjawab sangat setuju $33,33 \%$, setuju $57,78 \%$, netral $6,67 \%$, dan tidak setuju $2,22 \%$. 


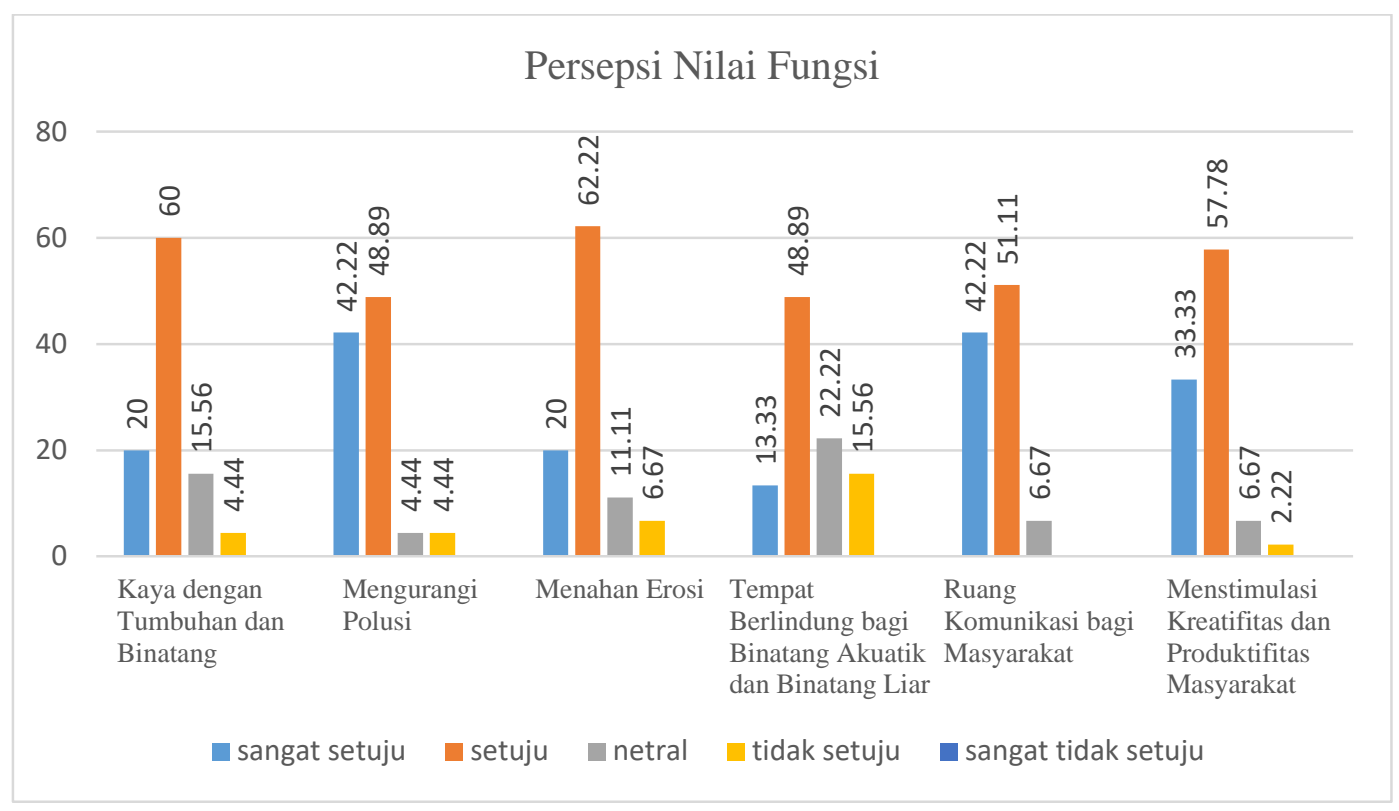

Gambar 4. Persepsi Nilai Fungsi Tukad Bindu

Nilai estetika Tukad Bindu juga mendapatkan respon yang positif dari responden. Secara rinci pendapat bahwa Tukad Bindu memiliki tema taman yang menarik responden menjawab setuju $57,78 \%$ diikuti sangat setuju $31,11 \%$, dan netral $11,11 \%$. Pendapat bahwa Tukad Bindu memberikan kesan hijau responden menjawab sangat setuju $26,67 \%$, setuju $71,11 \%$, dan netral $2,22 \%$. Responden yang sangat setuju dengan pendapat bahwa elemen desain bervariasi adalah $13,33 \%$, setuju $53,33 \%$, netral $26,67 \%$, dan tidak setuju $4,44 \%$. Pendapat bahwa hubungan antara lokasi dengan lingkungan terlihat harmonis responden menjawab sangat setuju $35,56 \%$, setuju $53,33 \%$, dan netral $11,11 \%$. Persepsi bahwa tumbuhan tertata dengan baik responden menjawab sangat setuju $15,56 \%$, setuju $57,78 \%$, netral $22,22 \%$, dan tidak setuju $4,44 \%$. Mengenai desain perkerasan permukaan jalan terlihat rapi responden menjawab sangat setuju 17,78\%, setuju 62,22\%, netral $17,78 \%$, dan tidak setuju 2,22\%. Pendapat bahwa Tukad Bindu menyajikan kualitas lanskap yang tampak alami responden menjawab sangat setuju $26,67 \%$, setuju $57,78 \%$, netral $11,11 \%$, dan tidak setuju $4,44 \%$.

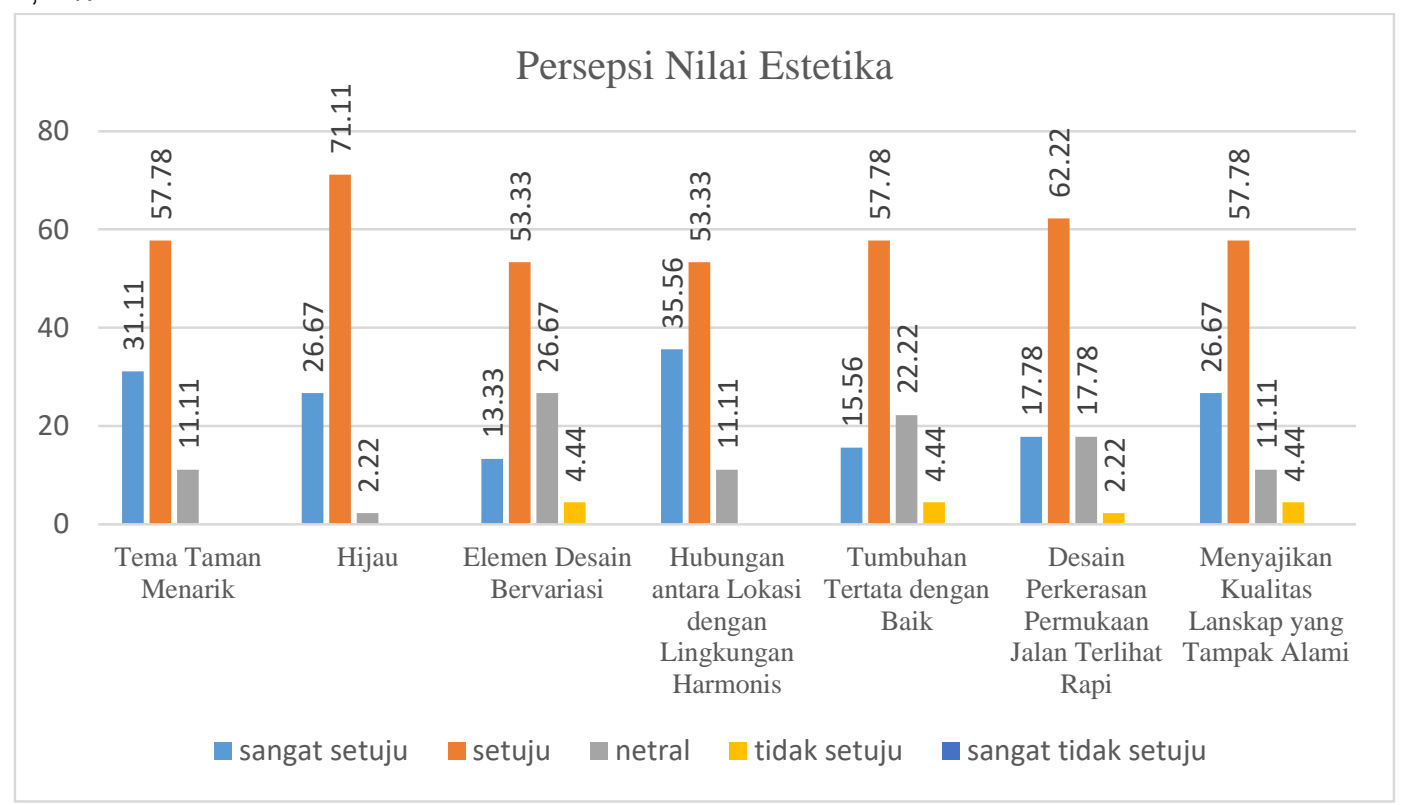

Gambar 5. Persepsi Nilai Estetika Tukad Bindu 
Berdasarkan observasi, tingginya nilai positif Tukad Bindu pada pernyataan kaya dengan tumbuhtumbuhan dan binatang, dapat mengurangi polusi, menahan erosi, sebaga tempat berlindung bagi binatang akuatik dan binatang liar, hijau, dan menyajikan kualitas lanskap yang tampak alami adalah karena penataan Tukad Bindu yang tidak banyak mengubah bentuk alami dan memiliki banyak tanaman (Tabel 1). Tingginya nilai positif pada pernyataan sebagai ruang komunikasi bagi masyarakat dan dapat menstimulasi kreatifitas dan produktifitas masyarakat dapat disebabkan oleh Tukad Bindu yang banyak menyediakan ruang diskusi serta elemen desain yang bervariasi. Terdapat kegiatan aktif yang terjadi di Tukad Bindu seperti permainan air yang juga didukung dengan disediakannya toilet umum serta tempat penyewaan ban dan selancar air. Selain itu, Tukad Bindu juga menyediakan tempat bermain anak dan lapangan olahraga. Hal ini dapat menjadi penyebab tingginya nilai positif pada pernyataan bahwa Tukad Bindu memiliki tema taman yang menarik.

\subsection{Preferensi Pengguna Tukad Bindu terhadap Penataan Tepi Sungai}

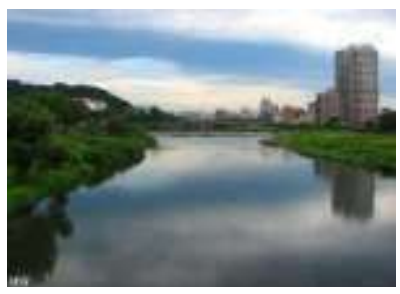

(a)

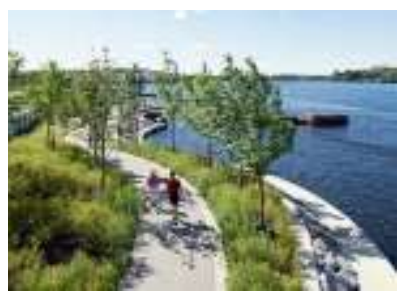

(c)

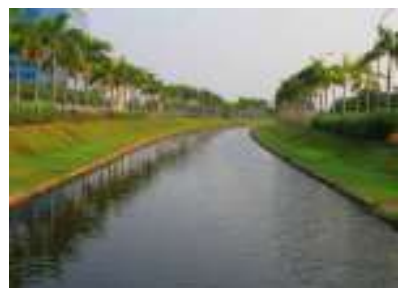

(b)

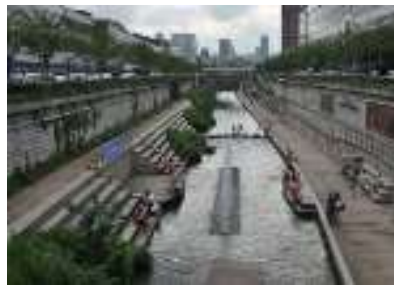

(d)

Keterangan: a: $100 \%$ softscape, b: $70 \%$ softscape, c: $50 \%$ softscape, d: $30 \%$ softscape

Gambar 6. Ilustrasi Penataan Riparian Dengan Berbagai Proporsi Hardscape dan Softscape (Sumber gambar: www.google.com)

Data preferensi yang diinginkan dari responden adalah preferensi mengenai desain lanskap tepi sungai. Responden dipersilahkan untuk memilih gambar pada Gambar 6 yang merupakan referensi yang mewakili desain tepi sungai dengan empat kriteria yang berbeda. Beberapa kriterianya pertama adalah tepi sungai dengan desain (a) 100\% softscape, kriteria kedua adalah penataan dengan (b) 70\% softscape dan 30\% hardscape, kriteria ketiga adalah penataan dengan (c) 50\% softscape dan 50\% hardscape, dan kriteria ke empat adalah penataan dengan (d) 30\% softscape dan 70\% hardscape. Responden dapat memilih lebih dari satu referensi gambar pada kuesioner.

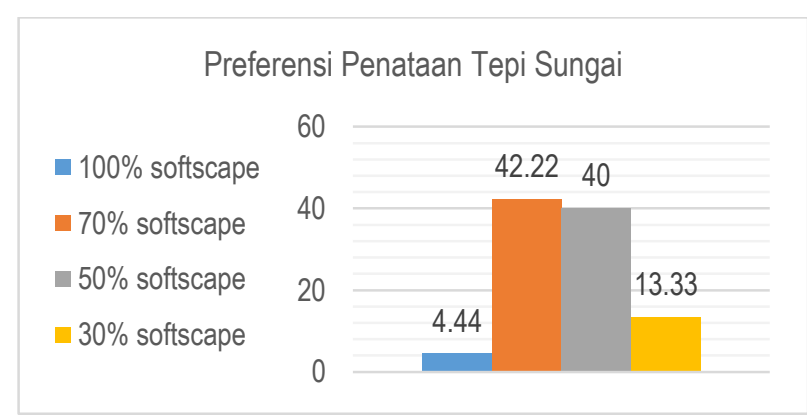

Gambar 7. Preferensi Penataan Tepi Sungai Bindu 
Berdasarkan Gambar 7 dapat diketahui bahwa 42,22\% responden lebih memilih desain dengan kriteria 70\% softscape dan 30\% hardscape. Preferensi Ini mendukung hasil studi Kenwick pada tahun 2009 mengenai zona riparian di Illinois, Amerika Serikat, yang menyatakan bahwa masyarakat lebih memilih sempadan sungai yang didominasi oleh softscape dibandingkan dengan hardscape. Desain dengan kriteria 100\% softscape adalah yang paling sedikit dipilih oleh responden. Salah satu alasan yang diberikan oleh responden adalah karena tidak adanya pembatas antara air dan daratan sehingga tidak ada pembatas yang menahan air dan alasan lainnya adalah karena kurang menarik. Sedangkan berdasarkan peran dan manfaat tata hijau pada bantaran sungai adalah untuk meningkatkan resapan air, mengurangi erosi tanah, dan untuk meningkatkan estetika lingkungan (Nurisyah dkk., 2015).

\section{Simpulan}

Hasil dari inventaris data pengunjung Tukad Bindu didominasi oleh pengunjung dengan jenis kelamin laki-laki. Tukad Bindu didominasi oleh pengunjung dengan usia 18-24 tahun yang menunjukkan tempat ini menarik bagi pengunjung dengan kelas usia muda yang produktif. Tukad Bindu didominasi oleh pengunjung yang berpendidikan terakhir SMA. Dari segi profesi, Tukad Bindu didominasi oleh pengunjung dengan profesi sebagai pegawai swasta. Berdasarkan observasi, pengunjung Tukad Bindu didominasi oleh orangtua yang berkunjung dengan mengajak serta anaknya untuk bermain. Dari segi intensitas, Tukad Bindu didominasi oleh pengunjung yang baru pertama kali berkunjung. Pada segi jarak tempuh pengguna, Tukad Bindu didominasi oleh pengguna dengan jarak $1-5 \mathrm{~km}$ hal ini dapat menunjukkan bahwa masyarakat cenderung mengunjungi tempat rekreasi yang jaraknya relatif dekat dan mudah dijangkau dari tempat tinggal mereka. Jarak ini dapat menjadi salah satu acuan untuk menempatkan ruang terbuka publik.

Berdasarkan hasil analisis dari data persepsi pengunjung terhadap Tukad Bindu, tidak ada nilai negatif yang persentasenya melebihi nilai positif. Pernyataan yang mendapatkan nilai negatif cukup tinggi adalah nilai fungsi sebagai tempat berlindung bagi binatang akuatik dan binatang liar (15,56\%). Hasil dari analisis ini dapat menjadi evaluasi bagi penataan dan perawatan Tukad Bindu selanjutnya. Rekomendasi yang diberikan berkaitan dengan hasil dari preferensi responden yang menunjukkan bahwa responden menginginkan desain lanskap tepi sungai dengan kriteria $70 \%$ softscape dan $30 \%$ hardscape.

\section{Daftar Pustaka}

Hair, J.F. (1995). Multivariate data analysis with reading (4th ed.). New Jersey: Prentice Hall

Kenwick, R. A., Shammin, M. R., Sullivan, W. C. (2009). Preferences for riparian buffers. Landscape and urban planning. Retrieved from: www.elsevier.com/locate/landurbplan

Jungels, J., Rakow, D. A., Allred, S.B., \& Skelly, S.M. (2013). Attitude and aesthetic reactions toward green roofs in the Northeastern United State. Landscape and urban planning. Retrieved from: www.elsevier.com/locate/landurbplan

Nurisyah, S., Pramukanto, Q., Nailufar, B. (2015). Tata hijau bantaran sungai kota. Buku pengetahuan praktis - IALI 2015

Sekaran, U. (2016). Metode penelitian bisnis. Jakarta: Salemba Empat

Sugiyono. (2011). Metode penelitian kuantitatif, kualitatif, dan R\&D. Bandung: Afabeta 